IRSH 63 (2018), Special Issue, pp. I 3 I-I 50 doi:I0.I0I7/So0208590I 800025 I

(C) 2018 Internationaal Instituut voor Sociale Geschiedenis

\title{
Exile as Imperial Practice: Western Siberia and the Russian Empire, I 879-I900*
}

\author{
ZHANNA POPOVA \\ International Institute of Social History \\ Cruquiusweg 3I, IOI9 AT, Amsterdam, The Netherlands \\ E-mail: zhannapop@gmail.com
}

\begin{abstract}
AвSTRACT: More than 800,000 people were exiled to Siberia during the nineteenth century. Exile was a complex administrative arrangement that involved differentiated flows of exiles and, in the view of the central authorities, contributed to the colonization of Siberia. This article adopts the "perspective from the colonies" and analyses the local dimension of exile to Siberia. First, it underscores the conflicted nature of the practice by highlighting the agency of the local administrators and the multitude of tensions and negotiations that the maintenance of exile involved. Secondly, by focusing on the example of the penal site of Tobolsk, where exile and imprisonment overlapped, I will elucidate the uneasy relationship between those two penal practices during Russian prison reform. In doing so, I will re-evaluate the position of exile in relation to both penal and governance practice in Imperial Russia.
\end{abstract}

\section{INTRODUCTION}

This article analyses exile to Siberia at a time of reform of the Russian penal system. By adopting the "perspective from the colonies" and investigating the local specificities of exile in Western Siberia, I will discuss how tension arose between attempts at prison reform and efforts to expand and consolidate the Russian Empire.

In the Russian context, exile is often perceived as direct expulsion of criminals and political offenders from central areas of the Russian Empire to its eastern borderlands. However, closer analysis of the exile system and the chaotic arrangements that contributed to its persistence makes clear the degree to which its shape was, in fact, defined by local rather than central authorities. For this article, I have examined the history of exile from the Siberian perspective and analysed the

\footnotetext{
* The research for this article is part of the research programme "Four Centuries of Labour Camps: War, Rehabilitation, Ethnicity", based at the International Institute of Social History (IISH) and the NIOD, Institute for War, Holocaust and Genocide Studies, Amsterdam, and funded by the Netherlands Organization for Scientific Research (NWO).
} 


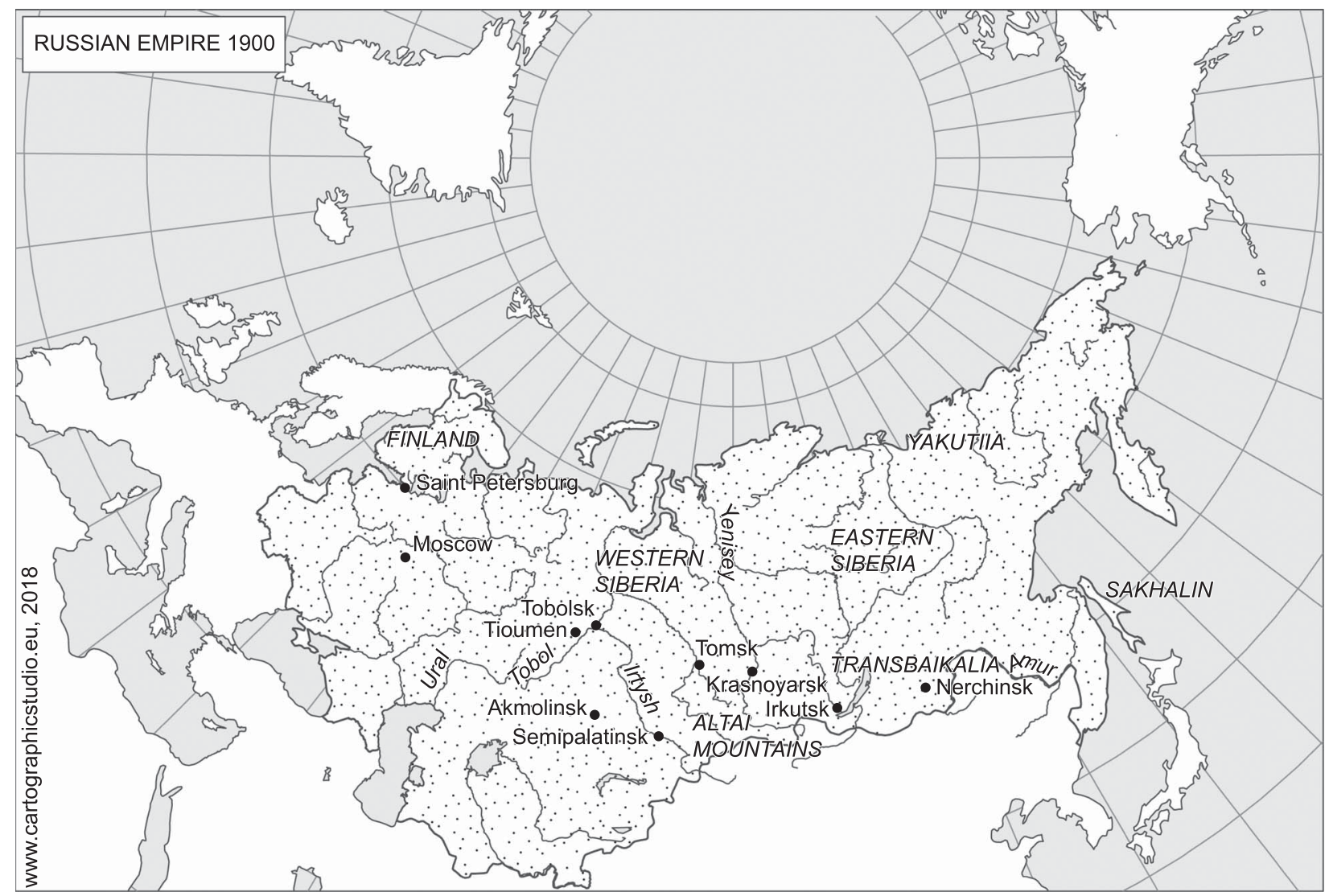

Figure I. Russian Empire, c.1900. 
role of exile within the wider repertoire of imperial policies in Western Siberia. ${ }^{\mathrm{I}}$

I challenge the view that Russian exile was a simple process of expulsion by placing in the foreground the nature of exile as a spatially complex and entangled imperial practice. My focus is Western Siberia and I have traced the various punitive flows that went through that region during the last decade of the nineteenth century. At the heart of this article are two interrelated questions. What were the various goals of exile and how were they connected to the relationships of power between the central and local authorities in the Russian Empire? ${ }^{2}$ How did exile and incarceration interact within the imperial penal architecture, especially in hinterland regions such as Western Siberia, and what impact did such interactions have on the penal system overall? This double movement foregrounds the decentralized character of exile, and, more importantly, allows the history of those Russian punitive practices to be reconnected with the wider history of Imperial Russia.

Exile implies forced displacement, so I have sought to be attentive to its spatial dimension and fluid character, instead of concentrating purely on the legal norms that prescribed it. For the same reason, it seems counterproductive to attempt to analyse it as a "system", for to do that would unnecessarily solidify it. Looking at exile as a "practice" rather than a "system" allows us to analyse the practical arrangements of exile and its political implications beyond its legal framework.

Western Siberia is a vast region to the east of the Ural Mountains, reaching from the Arctic Ocean in the north to the steppes in the south. The first Russian military colonizers arrived there at the end of the sixteenth century and, soon, a scattered network of military strongholds was constructed on the shores of the major Siberian rivers. Not long after, the first exiles from European Russia were banished to those lands and by the beginning of the nineteenth century both Western and Eastern Siberia had become traditional destinations for exiles in the Russian Empire. Within Russian pan-imperial exile architecture, Western Siberia played an important role as a convict transport hub too. Exiles from European Russia were categorized and distributed within the regions of Siberia after they had crossed the Ural Mountains. Exile's persistence over more than three centuries created the image of Siberia as "hell on earth", a "vast roofless prison".

I. For more on Russian imperial history see Jane Burbank, Mark von Hagen, and Anatolyi Remnev (eds), Russian Empire: Space, People, Power, I700-1930 (Bloomington, IN, 2007). For the Siberian case see Sergei Glebov, Region v istorii imperii. Istoricheskie esse o Sibiri (Moscow, 2013).

2. It is important to acknowledge that talking about "the central authorities" involves a significant simplification, albeit necessary for this article. The central authorities consisted of various groups with different interests, as noted in L.M. Dameshek and A.V. Remnev (eds), Sibir v sostave Rossiiskoi imperii (Moscow, 2007). 
Exile to Siberia remained the main Russian punitive practice throughout the nineteenth century and, as in other imperial contexts, was "a key aspect of imperial sovereignty". ${ }^{3}$ Certainly, there were considerable differences between the penal transportation overseas typical of the Western colonial empires and the internal continental exile peculiar to the Russian Empire. The differences were connected to the wider matter of colonization in Russian imperial history, and, as the prominent nineteenth-century historian Vassily Klyuchevsky famously stated, "the history of Russia is the history of a country which colonizes itself", thereby placing the colonization of Siberia within the centuries-long history of Russian peasant migrations. Indeed, debate continues on the nature of Russian policy in Siberia. ${ }^{4}$

The strongest evidence for understanding the interrelation between exile and imperial policy in general is provided by developments in the last third of the nineteenth century, when the penal regime of hard labour (katorga) fell away in the decades following the emancipation of the serfs in I86I. Experiments with various other regimes of incarceration and exile then began in the late I870s, and there was an eventual decision to curtail exile in I 900.

\section{EXILE WITHIN THE IMPERIAL PUNITIVE REPERTOIRE}

The Russian imperial penal system was the opposite of what Michel Foucault called a "monotonous punitive system". 'The penal system conceived by Foucault was based on control and discipline and was dominated by incarceration, whereas the Russian penal system throughout the nineteenth century included a wide range of punitive practices with very different premises. Exile stands in particularly stark opposition to Foucault's ideal of ubiquitous state control, for, in the overwhelming majority of cases, it meant not only expulsion, but also abandonment by the state.

Exile, incarceration, forced labour, and corporal punishment coexisted until the end of the Russian Empire, although they emerged under different historical conditions. For instance, exile to Siberia was first used as early as the seventeenth century, while "rehabilitative" intramural prison labour was introduced only relatively shortly before the revolution and was closely associated with the advance of modernity. During the nineteenth century, certain legal and administrative aspects of the penal system changed, but the reforms typically either had limited geographical impact, or took decades to

3. Christian G. De Vito and Alex Lichtenstein, "Writing a Global History of Convict Labour", International Review of Social History, 58:2 (2013), pp. 285-325, here 303.

4. For an overview of the debate, see Martin Aust, "Rossia Siberica: Russian-Siberian History Compared to Medieval Conquest and Modern Colonialism”, Review (Fernand Braudel Center), 27:3 (2004), pp. I 8 I-205.

5. Michel Foucault, "La poussière et le nuage", in Michelle Perrot (ed.), L'impossible prison. Recherches sur le système pénitentiaire (Paris, I980), pp. 29-39, here 30. 
implement; or they were never fully realized. That was most notably the case first with the legal reform of exile designed by Mikhail Speransky in the $1820 s^{6}$ and then with the restrictions on the use of corporal punishment introduced in 1863,7 as well as with the centralization of the prison administration that began with the creation of the Main Prison Administration in I 879. Certain regimes, such as katorga - the harshest punishment for common criminals - were never consistently reformed. The histories of exile and katorga are similarly closely interconnected.

Corporal punishment, incarceration, and exile could be used not only separately depending on the gravity of the crime committed, but also combined within a single penal regime, as was the case with katorga. Katorga was a harsh punitive regime intended for those convicts deemed the most dangerous, and it included forced labour for terms of from four to twenty-five years, followed by "eternal settlement" in Siberia. During the eighteenth century, an overlapping of different punitive measures was initially guided by a complex state agenda. The state was interested not only in the punishment of criminals, but also in the concentration of coerced convict workers in places that would benefit the state, be they naval construction sites in Petrine Russia or the Nerchinsk silver mines during Catherine's reign. In the eyes of the central authorities, exile was not purely an instrument for the punishment of convicts, for in itself the presence of exiles in the region assisted the Russian goal of colonization. On I 3 December $1760,{ }^{8}$ the Senate passed one of the principal laws that shaped the practice of exile, by which landowners were allowed to send "unruly" peasants into exile in the region of Nerchinsk in Eastern Siberia. As noted by the historian A.D. Kolesnikov, that law was a response to the growing financial needs of the state, to satisfy which the government sought to augment the volume of silver mined at the state-owned Nerchinsk silver mines. ${ }^{9}$ They did so by delegating to landowners the power to punish any perceived wrongdoing. Landowners were allowed to expel only healthy male peasants younger than forty-five years old, and if such men had dependent families the law encouraged the landowners to banish the men's families, too, although with financial compensation from the government. ${ }^{10}$ That law, therefore, laid a legal foundation for two ways of coercing the peasant population, namely by displacing them and by forcing

6. Andrew A. Gentes, Exile to Siberia, I590-I822 (Basingstoke and New York, 2008), pp. I65-20I.

7. Abby M. Schrader, "The Languages of the Lash: The Russian Autocracy and the Reform of Corporal Punishment, I8 I7-I 893" (Ph.D., University of Pennsylvania, I996).

8. Polnoe sobranie zakonov Rossiiskoi Imperii, First Series, Vol. XV (St Petersburg, I830), no. II 66 , p. 582.

9. A.D. Kolesnikov, "Ssylka i zaselenie Sibiri", in L.M. Goriushkin et al. (eds), Ssylka i katorga v Sibiri (XVIII-nachalo XX v.) (Novosibirsk, 1975), pp. 38-59, here 42-44.

ı. Polnoe sobranie, Vol. XV, no. i i 66 , p. 582. 
them to work for the state, while at the same time further privileging landowners. The decision to banish a peasant remained dependent purely on the whim of a landowner, thereby extending landowners' power over peasants. On the one hand, this early form of exile was a form of labour coercion in response to labour shortage; on the other, it helped facilitate the fulfilment of the "state interest in the population (zaselenie)" of Siberia proclaimed by the law.

The central Russian authorities were seeking to populate the vast Siberian territories with Russian peasants, and the administrative measures mentioned above provided a sizeable influx of people. According to Kolesnikov's calculations, in $\mathrm{I} 76 \mathrm{I}-\mathrm{I} 78 \mathrm{I}$ exile had a considerable impact on the population of Siberia, with at least 35,000 male peasants arriving there during that time. Kolesnikov suggests that the number of women who followed their husbands typically constituted up to eighty per cent of the number of men, suggesting therefore that the total number of adult peasants was around 60,000. ${ }^{\text {II }}$ According to the censuses, or revizii, of 1762 and I 782 , the total population of Siberia in those years comprised 393,000 and 552,000 males respectively. However, the Russian state's aspiration to use the exiles as workers in the silver mines met with limited success. Only a few of them settled around Nerchinsk in Eastern Siberia, while others were settled around the Siberian Route (Sibirskii trakt) in the southern part of Siberia. ${ }^{12}$ The bulk of the labour force in the Nerchinsk mines comprised criminals serving katorga hard labour terms. Again, according to Kolesnikov, despite the hardship of their forced displacement a number of the exiled peasants were able to settle and support their families, so that in the mid-nineteenth century in the region of Tobolsk the descendants of the exiled amounted to ten per cent of the population. In more distant regions of Eastern Siberia the percentage was higher ${ }^{13}$ and at the end of the eighteenth century administrative exile had clearly had an impact on the colonization of Siberia, albeit a limited one.

The plurality of the punitive regimes at the end of nineteenth century resulted from the fact that, throughout the century, the authorities that implemented the various punishments were guided not only by traditional goals such as retribution, deterrence, or, later, rehabilitation. Rather, they sought to fulfil the local goals of social control through expulsions and the disciplining of offenders, as well as the imperial agenda of colonizing territory to the east of the Ural Mountains.

I I. Kolesnikov, "Ssylka i zaselenie Sibiri”, p. 5 I.

I 2. This route is a historic road that connected European Russia to Siberia. Construction of it began in the early eighteenth century and, until the construction of the Trans-Siberian Railway and the Amur cart road at the end of the nineteenth century, it was the primary connection between Russia and China.

I 3. Kolesnikov, "Ssylka i zaselenie Sibiri", pp. 56-57. 
The official aspiration to use exile as an instrument to control and facilitate the colonization of Siberia partially explains the persistence of exile and katorga. Several other factors contributed to the complexity of the penal system. First, the estate system of the Russian Empire was reflected in the execution of punishment. Therefore, there existed two separate "ladders of punishment", one for the privileged estates, against whom corporal punishment was not used after 1785 , and the second for peasants and urban dwellers. In I 863 , the use of corporal punishment against the unprivileged was curbed, although it was still widely used as a disciplinary measure against those already serving sentences either of imprisonment or exile. That estate-based distinction persisted for the punishment of convicts, even though, on conviction, exiles of privileged origin were formally stripped of all their special rights.

Second, although the legislators' views on punishment and rehabilitation changed over time, that was rarely consistently reflected in the legislation. A growing desire to modernize the Russian Empire meant that various new laws were introduced along with new principles of organization of the penal system. However, they often contradicted the ones in use, which contributed to further complications. In the eighteenth century the ideas of revenge and deterrence guided the modalities of punishments and their execution, ${ }^{\mathrm{I}}{ }^{4}$ but, in the first half of the nineteenth century, Russian penology was heavily marked by John Howard's ideas about prison reform and the moral rehabilitation of criminals. ${ }^{\text {Is }}$ On I7 April i 863, a law was passed that brought to an end the practice of branding katorzhnye, who had, until then, had the letters "KAT" burned into their cheeks and foreheads. The lash, too, was abolished for the majority of convicts. Later, ideas of rehabilitative convict labour attracted the particular attention of officials, for such ideas promised not only improvements in prison discipline, but also offered the possibility of easier reintegration into society for former convicts. That interest resulted in a law of 6 January I 886 that prescribed mandatory labour for all prisoners. The act did not touch upon katorga hard labour, which was still, at least in theory, purely retributive. In practice, however, reports by the Main Prison Administration show that katorga institutions were in decline and many convicts in them did no work of any kind. Organizing and maintaining convict labour in the distant regions of the empire proved to be expensive, and as the central state's

14. Sergeui Poznyshev, K voprosu o preobrazovanii nashei katorgi (Moscow, I9I4), p. 4. For more on early-modern Russian punishments, see Nancy Kollmann, Crime and Punishment in Early Modern Russia (Cambridge, 201 2), and Evgenii Anisimov, Dyba i knut. Politicheskii sysk $i$ russkoe obschestvo v XVIII veke (Moscow, 1999).

I 5. John Howard was a British prison reformer. He inspected various British prisons and compiled a report, published as John Howard, The State of the Prisons in England and Wales (Warrington, I780). Michel Foucault has addressed Howard's work in Michel Foucault, Madness and Civilization: A History of Insanity in the Age of Reason (New York, 1988), pp. 44-64. 
interest in such institutions waned the local prison governors proved unable to continue enforcing convict labour.

Third, there existed a significant gap between the law, and local practice of prison and exile administration. The gap often proved to be particularly wide between the newly opened central experimental prisons, where the innovations were successful and discipline was maintained, and the decaying overcrowded prisons in distant regions. The difference was exacerbated by insufficient funding and a lack of qualified administrators and prison staff, as prison reform relied largely on the initiative of local prison governors in organizing the mandatory labour. In a number of reports from the i870s, the Governor General of Western Siberia complained at length about the low level of education of his subordinates. Moreover, combined with the lack of first-hand information about the condition of exile, the implementation of the state's conceptions of punishment could entail additional pain for the exiles. Daniel Beer has made an important observation here: "the yawning gulf between the state's own conception of deportation as a strictly logistical operation, on the one hand, and the convicts' experience of it as a brutal ordeal, on the other, reflected the weaknesses and limitations of the autocracy". ${ }^{16}$

At the end of the nineteenth century, there were officially eight categories of exiles whose status differed in the extent of the deprivation of their rights and the lengths of their terms, plus the category of katorzhnye, the convicts deemed the most dangerous. Exile to Siberia was not only a punitive measure and therefore not only part of the criminal justice system, but also an embodiment of the state's desire to control the colonization of Siberia. To a lesser extent, it was also an instrument of communal self-governance. Rural and urban communities (obschestva and meschanstva) could expel their "undesirable" members to Siberia. Many such expelled members of communities had, in fact, been trying to return to European Russia after serving their terms within the penal system, so that administrative exile could turn out to be a second, non-judicial punishment. By law, administrative exiles became members of communities in Siberia, even though other members of those communities might consider them burdensome and more than one community opposed the practice of administrative exile by complaining to local and central authorities. ${ }^{17}$

Such legal categorization might lead us to assume that it was somehow reflected in the experience of the exiles themselves in Siberia. However, even the state officials admitted that, in practice, the overwhelming majority of

16. Daniel Beer, "Penal Deportation to Siberia and the Limits of State Power, I80I-8I", Kritika: Explorations in Russian and Eurasian History, I6:3 (2015), pp. 620-650, here 62 I-622.

I7. Russian State Historical Archive [hereafter, RGIA], f. I 49, op. I (D.Z.), d.60, 11.33-38. I have used the usual classification for the Russian archives. Referring to the archival documents, I have used the common taxonomy "fond-opis-delo-(list)". "Fond" is collection, "opis" is a list of files, "delo" is a file, and "list" is a page. 
exiles of all categories experienced extreme hardship and were generally forced into the same condition of utter penury, which made many of them abscond from their assigned places of settlement. For example, in his annual report for 1875 , the Governor General of Western Siberia complained that of 70,000 exiles more than 36,000 were not living in their designated places of exile and had not informed the authorities of their departure. ${ }^{18}$ For the exiles, the main difference that belonging to one of the official categories entailed was the destination of their displacement. There was a distinct differentiation between regions in Siberia, for according to the view of the administrators the harsher the punishment a person deserved, the further east they should be sent.

Quantitatively, the largest category were the "administratively exiled", ${ }^{\text {I9 }}$ who were generally sent to the Tomsk or Tobolsk regions - unless they asked to be sent even further east. ${ }^{20}$ They were exiled to Siberia because their communities or, as serfs prior to I86I, their owners had banished them. They were generally allocated to rural communities in Siberia and considered by the legislators to be in a favourable situation. After terms of at least five years they were allowed to resettle or return to European Russia, although not to the communities that had expelled them. In practice, however, it appears that the radical experience of uprooting and social and geographical dislocation had a lingering and devastating effect on the majority of exiles. It also seems from the documents that those consequences were neither intended as part of their punishment, nor even predicted by the central government. In I900, the head of the Main Prison Administration remarked,

Even if it had been possible to make an assumption (purely theoretical and refuted by practice) that after a certain period of exile the nefarious members of society would lose their nefariousness, then what kind of correction can we expect from a person who spent only three years in exile, considering that the first years of the exile are the hardest time of settlement, the unescapable time of complete penury and extreme privation of necessary things that might engender not correction and repentance, but rather rancour. ${ }^{2 \mathrm{I}}$

Critical remarks like those, as well as the mention of any contradiction between "theory" and "practice", were possible only at the very end of the nineteenth century; before then, the discussion of exile was dominated by abstract moral arguments. Similarly, the first consistent data on the number of exiles appeared only at the end of the ir870s. By the end of the

18. RGIA, Vsepoddaneishii otchet general-gubernatora Zapadnoi Sibiri za I875 g., p. 25.

19. Kolesnikov, "Ssylka i zaselenie Sibiri", p. 57.

20. Aleksandr Salomon, Ssylka v Sibir. Ocherk eia istorii $i$ sovremennago polozheniïa (St Petersburg, I900), pp. IOI-IO2.

21. Ibid., p. I02. 


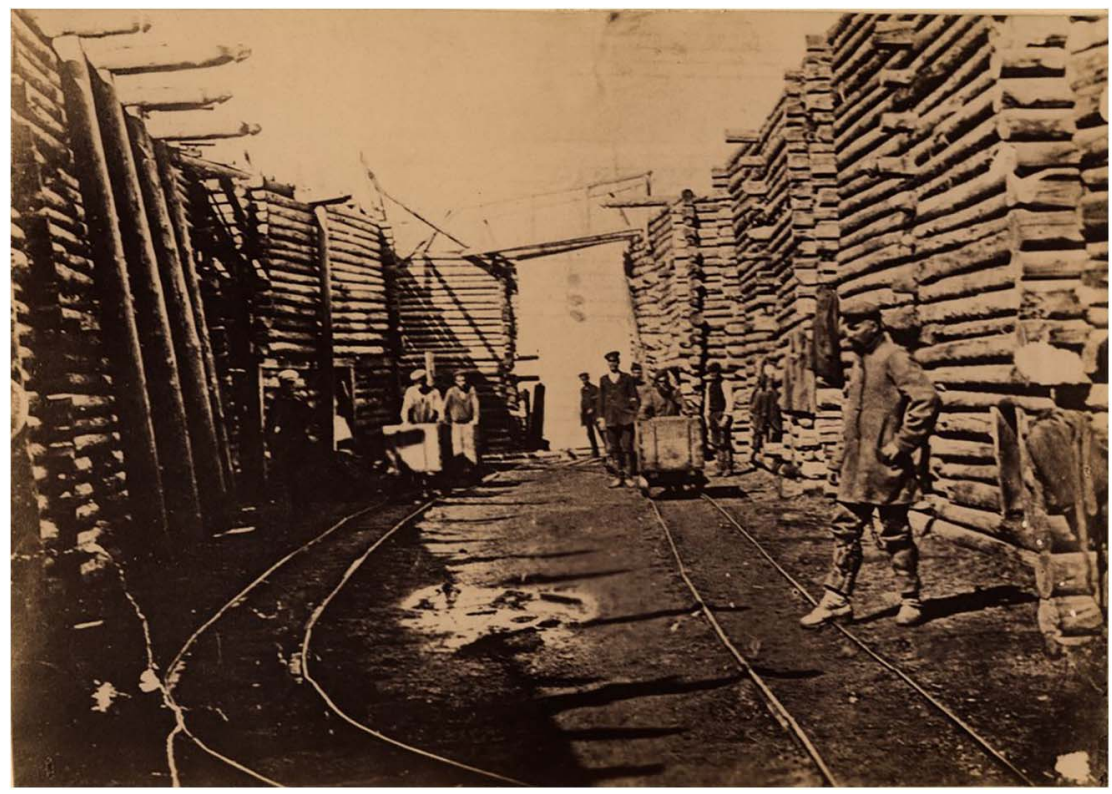

Figure 2. Hard labour in Eastern Siberia: Exiled convicts hauling cargo from the barges to the storage facilities in Transbaikalia, I89r.

World Digital Library https://www.wdl.org/en/item/ı 8972/. Photo by Aleksei Kuznetsov. Used by permission.

century (in I897-I898), the province of Tobolsk was home to I03, I02 administrative exiles, while the region of Tomsk contained 35,736. ${ }^{22}$

The next three categories of exiles were those banished following court decisions, and initially such "exiled settlers" constituted the second most numerous category. All except those unable to do agricultural labour were banned altogether from living in cities, and unlike administrative exiles they were legally excluded from the social system. Exiled settlers were not allocated to any particular community (obschestvo) but had an estate of their own (soslovie) as exiles. ${ }^{23}$ In the second category were "settled workers", vagrants who had been sentenced to forced labour ${ }^{24}$ and of whom the majority were sent to the Irkutsk, Enisei, and Transbaikalia provinces in Eastern Siberia. Finally, there was a particularly small group of people "exiled for life"

22. Ibid., Appendix 4, pp. I4-I 5 .

23. Ibid., p. I03. Until I 822, the children of exiles and the katorzhnye were also attributed to this class from birth: Dameshek and Remnev, Sibir v sostave Rossiiskoi imperii, p. 277.

24. For more on the lives of vagrants in Siberia, see Andrew A. Gentes, "Vagabondage and the Tsarist Siberian Exile System: Power and Resistance in the Penal Landscape", Central Asian Survey, 30:3-4 (2011), pp. 407-421. 
(soslannye na zhit'e). They were privileged individuals who had committed crimes for which unprivileged people would have been imprisoned.

The remaining categories were quantitatively negligible and included political exiles, those exiled for up to five years under police surveillance, and criminals from Finland ${ }^{25}$ who had originally been sentenced to long prison terms but had chosen exile instead.

The most obvious thing about that list is the bureaucratic failure of the central administration. The categories of exiles were introduced more or less haphazardly, not systematically at all; moreover, the categorization had little impact on the condition of the exiles, who generally found themselves abandoned by the state rather than closely watched and controlled by its representatives.

\section{RUSSIA AND SIBERIA: IMPERIAL TENSIONS}

Exile can be understood only as part of a wider geometry of power. It was initiated by the central government, but its implementation involved actors located in different places and it was generally not centrally coordinated. Therefore, looking at exile in connection with Russian governance practice highlights the fact that penal exile was developed not only by the innovations of lawyers and ministerial administrators but also, less directly, by the tension between central and local authorities and the agenda of imperial expansion.

In their policies on Siberia, the central Imperial Russian authorities were guided by controversial desires. On the one hand, they strove to integrate Siberia better within the empire, provide it with qualified local administrators, and use the economic potential of the region; on the other, they had no wish to see the region develop enough political and economic autonomy and to contest matters with the central power. Each Russian emperor approached the dilemma differently. Nicholas I's attempt to resolve the matter saw him appoint the First Siberian Committee, which, dominated by Prince Gorchakov, "made a conscious decision to keep Siberia backward and underdeveloped as the best way of bringing about the 'firm unification' and 'complete amalgamation' of Siberia with central Russia". ${ }^{26}$ By contrast, Alexander II's government brought in a new paradigm of thinking about Siberia and how it might be possible to unify it with Russia. Their plan was to break down its administrative separateness, ${ }^{27}$ a process accelerated under

25. The Grand Duchy of Finland was an autonomous part of the Russian Empire and thus its people, too, were subject to special policies. The choice on conviction of either incarceration, or exile was one of their privileges.

26. Steven G. Marks, Road to Power: Trans-Siberian Railroad and the Colonization of Asian Russia, I850-19I7 (Ithaca, NY, I99I), p. 49.

27. S.G. Svatikov, Rossiia i Sibir: (k istorii sibirskogo oblastnichestva v XIX v.) (Prague, I929), p. 76. 
Alexander III until by i 887 "the very name Siberia was no longer used as an administrative term". ${ }^{28}$ On the eve of the twentieth century, administrative unification of Siberia with Russia became the dominant policy. ${ }^{29}$

Despite such efforts at integration, administration of punitive exile was always dependent on local authorities, whose role was crucial because sentences of exile did not include a destination. At the beginning of the nineteenth century, in special cases individuals might be exiled within European Russia, but consistently the main flow of criminal and administrative exiles was directed to Siberia. Within Siberia exile to different regions was considered to possess differing punitive force, with exile further east perceived as constituting a harsher punishment. ${ }^{30}$ It was, therefore, traditional for katorzhnye to be exiled to Transbaikalia or Yakutia, while Western Siberia received administrative exiles. The settler exiles were confined to the regions around Irkutsk and along the Amur River. ${ }^{3 \mathrm{I}}$ Distribution was arranged only after the exiles arrived in Siberia and was overseen by the Tioumen Office of the Exiled (Tioumenskii Prikaz o Ssylnykb), the regional Siberian prison inspectorate, and the regional offices. The Office of the Exiled was originally created in Tobolsk in I 822 as part of Speransky's reform of the system of exile, ${ }^{32}$ but, in I 869 , it was moved to Tioumen. Before the authorities began experimenting with the installation of katorga sites on Sakhalin in I869, criminal exiles were sent to various places in southern Siberia, such as Nerchinsk in Transbaikalia and Krasnoiarsk in Eastern Siberia. There was also a katorga prison in Tobolsk, but it was much less important than Nerchinsk or Sakhalin.

The logistics of exile were complex, with exiles very unevenly distributed throughout the region. In the second half of the nineteenth century, the presence of exiles in Western Siberia was limited, but concentrated. The highest concentrations of exiles were in regions that already had the highest population density, thus both exciting discontent among the locals and prompting an otherwise unlikely shortage of usable land.

The Tioumen Office assigned precise exile locations only to those exiled to the Tobolsk region, while in all other cases it recorded only the region of destination, leaving it to the local authorities to allocate the specific places to which exiles would go. Just like the Tioumen Office, certain of the regional authorities relied on information about available land provided by local

28. Marks, Road to Power, p. 53.

29. Dameshek and Remnev, Sibir v sostave Rossiiskoi imperii, p. 138.

30. RGIA, Vsepoddaneishii otchet general-gubernatora Zapadnoi Sibiri za I 876 g., p. 37. Tobolsk and Tomsk provinces received only administrative exiles while the Eastern Siberian provinces (Enisei, Irkutsk, Iakutsk, Amur provinces, Transbaikalia and Sakhalin) took criminal exiles and katorzhnye.

3I. See art. I 58 of the Code of the Exiles [Ustav o ssylnykh 1876 ].

32. Gentes, Exile to Siberia, pp. 179-180. 
governors. ${ }^{33}$ The area of exile changed significantly over time, and in Western Siberia in particular it gradually shrank. Initially, that was because of the organization of the Altai Mountain District (Altaiskii Gornii okrug) in I 808. ${ }^{34}$ As the personal property of the emperors and a significant source of profit, the Altai District was governed directly by the Imperial Cabinet. Another limitation was related to imperial policy concerning indigenous people, for convicts were not exiled to either Akmolinsk or Semipalatinsk in the southern part of Western Siberia. That was because of the imperial authorities' conception of the local nomadic Kyrgyz tribes, whom they were gradually trying to convert to Christianity. The central government presumed that "any contact with the vicious element [porochnyi element] would make the Muslim Kyrgyz horde stay in the depths of the steppes, aloof from all things Russian and Christian", ${ }^{35}$ which they considered would undermine all government efforts aimed at settlement and Christianization. Similarly, the northern regions of Western Siberia also did not host no exiles, for that would have required too much logistical effort to preserve the exiles from "dying of biting frost and hunger". ${ }^{6}$ In other words, only a small (compared to the overall surface of Western Siberia) area still received exiles in the last third of the nineteenth century, but their concentrations there were high.

The ratio between the number of exiles and the local population, according to legal prescriptions supposed to be limited to one in five, ${ }^{37}$ was also a matter of concern for the local administrators. On settling in Western Siberia, exiles and their families were granted allotments of three desiatiny (8. I acres) of arable land per person. ${ }^{38}$ However, research begun in 1875 by the Western Siberian Governor General Kaznakov shows that in the majority of regions that proportion of administrative exiles was far from being respected. After bringing the matter to the notice of the central government, Kaznakov stated that the relocation of those already exiled once, as well as the disposition of future exiles, should remain within the jurisdiction of local governors general. ${ }^{39}$ That resulted in no change in the condition of the exiles, but created a legal normalization of the situation. In I 88 I, Kaznakov issued an instruction that the new normal proportion of exiles to the local population (starozbily) should be one in three. ${ }^{4}$

\footnotetext{
33. Salomon, Ssylka, p. i I 7 .

34. Ibid., p. I 2 I.

35. RGIA, Vsepoddaneishii otchet general-gubernatora Zapadnoi Sibiri za I 877 g., p. 29.

36. RGIA, Otchet za $I 877$ g., p. 29. Exiles were indeed sent to the north of Western Siberia in Soviet times; for a case of the catastrophic and deadly failure of this endeavour, see Nicholas Werth, Cannibal Island: Death in a Siberian Gulag (Princeton, NJ, 2007).

37. Salomon, Ssylka, p. I22.

38. Ibid., p. I 23.

39. Journal of 27 September to 4 October 1879 of the Council of the Main Administration of Western Siberia, IAOO, Historical Archive of the Omsk Region), f.3, op.9, d.I 5872.

40. Salomon, Ssylka, p. I25.
} 
Local authorities sought to change the position of Siberia as the main exile destination in the Russian Empire, but they failed to do so and power over the definition of punishments remained firmly in the hands of the central government. Siberian authorities therefore remained obliged to accommodate exiles and adapt to their growing numbers.

\section{KATORGA AND THE CHANGING ROLE OF SIBERIA}

Among all the flows of punitive relocations to Siberia, the cases of those sentenced to katorga were the most complex, but they allow us to trace the interrelation between punitive relocation and imprisonment. The case of the Tobolsk katorga prison, therefore, deserves closer inspection. Tobolsk prison was an imperial institution where exile and detention overlapped, so that a study of the history of its establishment and functioning will highlight the uneasy relationship between those two types of punishment.

Before the arrival of the railways in Siberia, rivers were the main routes of commerce and communication. The town of Tobolsk, situated at the confluence of the Irtysh and Tobol rivers, had been one of the main outposts of the Russian presence in Siberia since the end of the sixteenth century. However, the choice at the end of the nineteenth century of a "Southern route" for the Trans-Siberian Railway led to the growing importance of more southerly towns such as Tioumen and Omsk and brought the economic development of Tobolsk to a halt. Over the first few decades of the twentieth century, Tobolsk then completely lost its commercial and administrative influence to Tioumen.

Nevertheless, at the end of the I870s, Tobolsk was still the seat of the governorate and the site of a number of distinctly imperial institutions, including two relatively new katorga prisons built in response to overcrowding in European Russia. ${ }^{4 \mathrm{I}}$ With the growth of the prison population in the I860-1870s after the emancipation of serfs and curtailment of corporal punishment, the existing katorga prisons had become insufficient to cope with the influx of new convicts.

The decision to create new katorga prisons in Tobolsk dates to I 874, when a former wine cellar was supposed to be refurbished as a huge prison cell. It is unclear exactly whose decision that was, but it most probably originated within the Ministry of Internal Affairs. However, before construction work could even begin 250 katorga convicts were sent to Tobolsk. As a transport hub for prisoners to be sent further east, Tobolsk had a prison stronghold (tiuremnii zamok) with space that could be utilized as a temporary jail for those inmates. In September I 876, a new and bigger katorga prison was opened in another part of the stronghold that had

4I. State Archive of the Russian Federation (GARF), f.r 22, op.5, d.743, I.I I. 
previously been a military prison, which, in June of that year, had been moved to the town of Ust-Kamenogorsk. The new katorga prison could accommodate 550 convicts and the temporary jail was transformed into its special section. The construction of a second katorga prison, for 300 prisoners, was completed at the end of 1878 .

Large groups of katorga prisoners from European Russia were confined in Tobolsk prison for the first part of their punishment. The principles of sorting those convicts who would stay in the European part of the empire and those who would have to be displaced further to the east were outlined in an ordinance of i 8 April i 869 drafted by a Special Committee responsible for exile reorganization..$^{42}$ Once again, these principles reflected the use of convicts as the embodiment of Russia's imperial expansion into Siberia. The mere presence of Russian men and, especially, women in Eastern Siberia was considered sufficient to fulfil the goal of colonization. Therefore, male convicts with families were sent to Siberia directly after their conviction, while single convicts remained to serve their term in Europe: convicts with families were deemed more capable of settling down and becoming well-established colonists after their release from confinement in a katorga prison. Regardless of their marital status, female convicts from all over the empire were also sent to Eastern Siberia. Abby Schrader discusses in detail the conception senior officials had of the socio-sexual order of the Siberian exiles and the instrumentalization of women for the purpose of domesticating male exiles. That underlines the role of views of gender in the policy of using exiles as colonists in Siberia. ${ }^{43}$ Unmarried prisoners and married convicts unaccompanied by their families generally remained in European Russia to serve at least the initial periods of their sentences.

Unlike some katorga prisons in Eastern Siberia, such as the one at the silver and lead mines of Nerchinsk, Western Siberian katorga prisons were not dedicated to one particular type of forced convict labour in the interest of the state. Despite forced labour constituting the core of the punitive regime of the katorga, the organization of convict labour in those prisons was clearly of less importance than their accommodation of incoming convicts. The author of the report on the condition of the Tobolsk katorga prisons, junior official [mladshii chinovnik] Merkushev, mentioned that discussions about the necessity of well-established convict labour began as early as I 875 with the opening of the temporary katorga jail. One type of work discussed was that needed for the canalization of the town, a typical example of extramural convict labour. However, the discussions had had no

42. "O predstoiashchem preobrazovanii katorgi”, Tiuremnyi vestnik, 6-7 (1910), pp. 897-922. 43. Abby M. Schrader, "Unruly Felons and Civilizing Wives: Cultivating Marriage in the Siberian Exile System, I 822-I 860”, Slavic Review, 66:2 (2007), pp. $230-256$. 
actual outcome at the time the report was written in February I 882 and the convicts were mostly set to work inside the prisons, doing tasks such as cleaning, cooking, and laundry. There were artisanal workshops, but their production was limited and destined mostly for private customers.

The overall impact of forced labour on prison life at the time of the Merkushev report was very limited. Both prisons together could accommodate I, I00 prisoners, but, unlike most in the Russian Empire at that time, were not employed at full capacity. ${ }^{44}$ However, the report states that the number of people forced to work both in the workshops and on prison maintenance almost never exceeded 250 in total, while other prisoners did no work at all. In other words, although prison governors in Tobolsk were not confronted with overcrowding they were nevertheless unable to ensure full employment for their charges.

The reports from the local prisons show the lack of coordination between the different parts of the penal system, with the practice of exile putting additional strain on the katorga prison. That convicts were sent to Siberia in spite of insufficient facilities awaiting them was just one example of such mismanagement. More importantly, discrepancies and shortfalls seem to have been inherent in the prison and exile management system as a whole, rather than specific to Tobolsk. The condition of prisons on the eve of reform was largely defined by problems of administration and communication. Bureaucratic inconsistencies together with fragmented and insufficient funding clearly produced a penal system within which conditions might differ dramatically depending on where prisons were.

Normal prisons were intended to house convicts serving shorter terms, while exile and especially katorga were designed as longer and harsher punishment. By the beginning of the twentieth century the condition of the katorga regime was considered critical and provoked a public outcry ${ }^{45}$ as the gap widened between new attitudes to punishment and the theoretical premises of katorga. Together with the continuous protests of the Siberian authorities and communities, that mismatch made the crisis of the whole system of katorga colonies more and more visible. The absence of any consistency in reform of katorga in the nineteenth century was ostensibly related to the installation of the penal colony on Sakhalin Island, for rather than reforming the regime of punishment officials of the Main Prison Administration opted to establish that major new site. In other words, they believed that in the I860s and later the katorga system was still valid and needed only to be employed more consistently and with better conditions. Some of those officials, most notably the head of the Main Prison

44. GARF f.I 22, op.5, d.743.

45. The public discussions of katorga were prompted by the publication of Chekhov's Sakhalin Island (1893), Doroshevich's Sakhalin (1903), and Tolstoy's Resurrection (1899). 


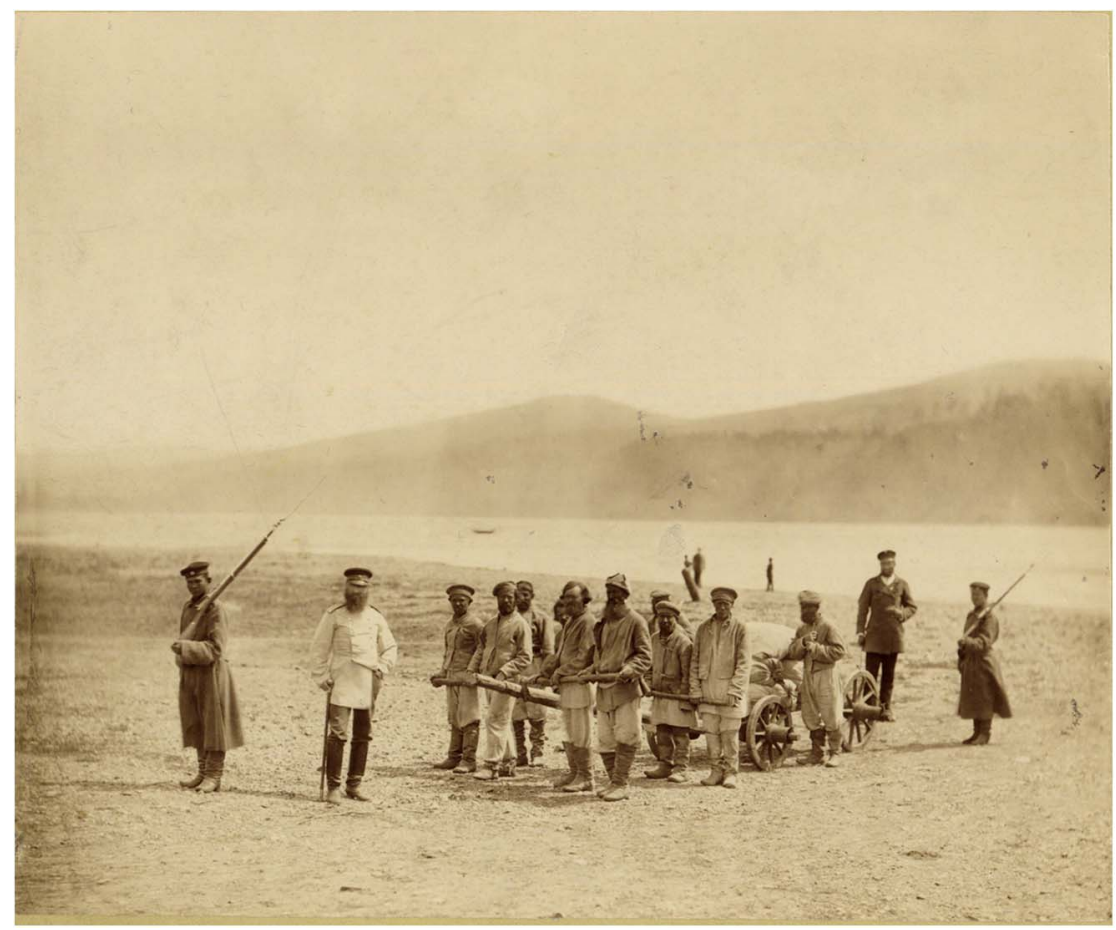

Figure 3. Katorga convicts in the Due coal mine on Sakhalin, i $890 s$.

World Digital Library https://www.wdl.org/en/item/ı8468/. Photo by Innokentii Pavlovskii. Used by permission.

Administration Mikhail Galkin-Vraskoi, considered Sakhalin Island to be the ideal location for a penal colony due to its remote geographical position, hostile weather conditions, and relatively small local population. In practice, however, it turned out that the establishment of a stable penal settlement based on the agricultural labour of convicts was scarcely possible. The weather was too unfavourable, the settlers needed constant supplies of food, and transport was expensive as, prior to the opening of the Suez Canal in I869, the convicts had to be shipped the long way round Africa from the Black Sea. Moreover, escapes turned out to be less rare than the officials of the Main Prison Administration had expected. The case of Sakhalin was just one example, although probably the most striking, of the gap between the imagination of Russian state officials and reality.

\section{PENAL REFORMS AND THEIR LIMITS}

The economic backwardness of the Russian Empire became painfully evident after its defeat in the Crimean War. Shortly after I 856 "the tsarist 
regime [embarked] on radical policies of economic, administrative and social modernisation", ${ }^{46}$ beginning with the emancipation of serfs and followed by judicial, educational, and administrative reforms. However, not all the reforms introduced in European Russia were introduced in Siberia, too, for as a border region Siberia existed under a different regime of governance, and the rhythm of change was different there as well.

The prison reform of 1879 was aimed at centralization of prison management in the Russian Empire. It did not bring immediate changes to the condition of the prisons or to the system of exile, but it did begin a long process of organizational change. The ultimate goal of the reform was to create a uniform prison system based on rehabilitation through obligatory artisanal labour in prison workshops. However, prison officials were confronted with the reality that prisons permanently lacked both funds and qualified officers, and that prison administrators preferred to employ convicts for unskilled extramural labour. Meanwhile, local authorities, preferring to rely on exile instead, were unwilling to build new prisons. Nevertheless, the spread of prisons in the last third of the nineteenth century remained consistent, if slow, and was much more prominent in European Russia than in Siberia, especially in densely populated regions. The whole architecture of exile proved less susceptible to attempts to centralize it and it effectively impeded the adoption of imprisonment as the dominant punishment.

Exile in general proved to be largely untouched by reform until the beginning of the twentieth century, for only then had it lost its appeal as an instrument to colonize Siberia. Natural population growth and especially the explosive increase in the rates of peasant colonization during the last decade of the nineteenth century eventually played a far more important role in that.

Throughout the nineteenth century, the remoteness of Siberia, both physical and in the imagination, was one reason for the persistence of the regime of sending convicts into exile both administratively and after trial. The central administrators could argue that the practice would make the "real" Russia, by which they meant its European part, safer. However, although as early as the nineteenth century dissenting voices considered the system brutal and costly, as it led to social dislocation and many deaths and injuries of people on their way to Siberia, ${ }^{47}$ pleas to curb it did not bring about a quick solution. Initial attempts in 1835 to reform the exile system continued sporadically and inconsistently for more than sixty years. For example, administrative exile of peasants banished by their communities or their

46. Dominic Lieven, "Russia as Empire and Periphery", in: Dominic Lieven (ed.), The Cambridge History of Russia, Volume 2. Imperial Russia, I689-I9I7 (Cambridge, 2006), pp. 7-26, I 2.

47. For more on conditions in exile, see Sarah Badcock, "From Villains to Victims: Experiencing Illness in Siberian Exile”, Europe-Asia Studies, 65:9 (2013), pp. 1716-1736. 
masters was at one time abolished, but then reintroduced less than two years later. The exile system was considered problematic and more than once the tsars suggested resolving matters ${ }^{48}$ but a major shift in the perception of exile was needed before agreement could be reached to curtail it.

At the end of the nineteenth century, the efforts of the Russian state to reinforce its position in Siberia were channelled into strengthening the region economically. Those efforts included improving communications by building the Trans-Siberian Railway and facilitating peasant resettlement from the European part of the empire. In the final decades of the Russian Empire's existence, primacy in empire-building was ascribed neither to the military, nor to administrative officials but to peasant colonists. ${ }^{49}$ Unprecedented waves of free migration, with approximately three million people arriving in Siberia in just fifteen years (I895-I9I0), ${ }^{50}$ swept away the lingering image of Siberia as a barren place of exile. High-ranking officials such as the Prime Minister Piotr Stolypin (I863-I9I I) as well as middle-ranking technocrats ${ }^{5 \mathrm{I}}$ and scholars like Matvei Liubavskii (1860-1936) defined the degree of integration of regions within the Russian state by their extent of peasant colonization. ${ }^{52}$ Promotion of peasant colonization of Siberia was therefore connected to administrative changes to the position of the region within the empire and the shift from administrative separation to integration. In discussions of reform, the changes provided administrators with convincing arguments for the abolition of exile $^{53}$ as they first insisted that exile was now less punitive and then that Siberia was becoming steadily more "Russian". Peasant colonization should, therefore, be encouraged instead of forcibly populating the region with convicts. Finally, a law of I 2 June I 900 abolished judicial exile and curtailed the administrative variety. According to some estimates, those two categories together constituted eighty-five per cent of all exiles. ${ }^{54}$ Subsequently, exile to Siberia was preserved only in the form of the administrative exile of political and religious offenders.

48. A.D. Margolis, Tiurma i ssylka $v$ imperatorskoi Rossii: Issledovaniia $i$ arkbivnye nakhodki (Moscow, I995), pp. I 5-2 I.

49. Anatolii Remnev, "Vdvinut Rossiiu v Sibir: imperiia i russkaia kolonizatsiia vtoroi poloviny XIX. Nachala XX veka", in Glebov, Region v istorii imperii, p. 48.

50. P.A. Stolypin and A.V. Krivoshein, Poezdka v Sibir' i Povolzhie (St Petersburg, I 1 I I), p. 2. 5 I. Peter Holquist, “In Accord with State Interests and the People's Wishes'”: The Technocratic Ideology of Imperial Russia's Resettlement Administration”, Slavic Review, 69:I (2010), pp. I I I-I79.

52. Matvei Liubavskii, Obzor istorii russkoi kolonizatsii s drevneishikh vremen i do XX veka (Moscow, 1996).

53. Extensive discussions on the abolition of exile can be found in Zhurnaly vysochaische uchrezhdennoi Komissii o meropriiatiakh po otmene ssylki. Zasedaniia 3 iunia, 9 i 16 dekabria I $899 \mathrm{~g}$., I0 ianvaria ${ }_{7}$ fevralia $1900 \mathrm{~g}$. (St Petersburg, I900).

54. Dameshek and Remnev, Sibir v sostave Rossiiskoi imperii, p. 288. 
So significant a reduction in the number of exiles facilitated the advance of prison reform. Over the ensuing decades prison administrators were able to achieve increasing uniformity in conditions between prisons in European Russia and in Siberia, especially in Western Siberia. In I9I3 the head of the Main Prison Administration could still lament conditions at the katorga sites in Transbaikalia, but he found the Tobolsk prisons acceptable. 5 Despite the fact that exile and katorga existed until the I917 Revolution, they lost their importance as standard punishments and, especially after 1905, became more prominent as instruments of repression against political militants.

\section{CONCLUSION}

The final decades of the nineteenth century were a time of rapid social and economic change in the Russian Empire, and the penal system, too, was changing, albeit at its own pace. Exile remained the cornerstone of punitive practice throughout the nineteenth century, despite attempts by prison administrators to promote prison as the dominant punitive regime. Even though exile had de facto a limited impact on the colonization of Siberia, the central authorities still relied on its alleged potential as they used exile forcefully to displace thousands of peasants and their families. Only as Siberia acquired a new role within the Russian Empire did exile lost its appeal for the central administrators. With unprecedented peasant migration during the last third of the nineteenth century, Siberia, and especially Western Siberia, increasingly came to be considered part of Russia's "core" rather than a colony. The changes were embodied in the law of 1900 , which curtailed administrative exile.

Looking at exile from the Siberian perspective provides a number of otherwise impossible insights. First, an analysis of the precise geographical organization of exile demonstrates the multitude of flows of punitive displacement and how those flows were differentiated, with exile further east considered more punitive. In other words, a Siberian perspective demonstrates how hinterland regions were organized within the imperial hierarchy and so underscores the variety of goals exile was supposed to fulfil, whether as punishment, to provide coerced labour, or for the colonization of border territories. Second, the case of the Tobolsk katorga prison demonstrates the limits of central government control as well as how the persistence of exile thwarted the advance of prison reform. Reform was impeded simultaneously by severe bureaucratic inefficiency and failed experiments. Finally, there was strong asymmetry in administrative and political structures, while local practice persisted. 